\title{
Research
}

\section{Implementing the Western Gulf of Maine Area Closure: The Role and Perception of Fishers' Ecological Knowledge}

\author{
$\underline{\text { Mateja Nenadovic }}^{1,2}, \underline{\text { Teresa Johnson }}^{2}$, and James Wilson $^{2}$
}

\begin{abstract}
The debate about the quality of fishers' ecological knowledge (FEK) and its value to fisheries management has long been present in the literature. This study sought to understand the role of FEK in a particular fisheries management decision in the U.S. and to evaluate the extent that different stakeholder groups recognized and used FEK in fisheries policy creation. The 1998 implementation of the Western Gulf of Maine Area Closure (WGoMAC) was a management response to the rapid decline in the Gulf of Maine cod (Gadus morhua) stock. Using structured surveys and semistructured interviews, we collected information from major stakeholder groups that were active during the creation of the area closure: New England Fishery Management Council (NEFMC) members, Groundfish Advisory Panel members, Groundfish Plan Development Team members, and Maine groundfishers. Results indicated that $95 \%$ of respondents believed that fishers possess ecological knowledge that could be useful in the fishery management process. In the case of the WGoMAC creation, $62 \%$ of respondents indicated that FEK played a role in the decision, even though $85 \%$ recognized obstacles to the use of FEK in the management process. Interviews demonstrated that FEK was able to improve upon the spatial resolution of scientific data by identifying seasonal migration patterns of prespawning cod and behavioral differences between juvenile and adult cod. This information was a product of a peer-reviewed process among groundfishers and it was used to fine-tune the exact location of the closure. These findings suggest that there are ways to incorporate FEK into fishery management for the purposes of stock and habitat conservation. Additionally, the benefit of having ecological information that spans different spatial scales for fishery management was observed in this study. By combining the knowledge systems of fishers and fisheries scientists, managers were able to capture ecological information at a finer scale than the scale at which landings data are reported and fish stocks analyzed.
\end{abstract}

Key Words: area closure; fisheries management; fishers' ecological knowledge; Gulfof Maine; issues of scale; Marine Protected Area (MPA); New England Fishery Management Council (NEFMC); social-ecological systems; spatial scale

\section{INTRODUCTION}

In the late 1990s fishery managers relied increasingly on area closures and other spatial management measures because conventional effort controls had repeatedly failed to achieve conservation goals (Agardy 1997). By adopting area closures fishery managers expect to protect areas with high fish concentrations and critical habitat (NRC 2002). In this paper, we look closely into the creation and outcome of the Western Gulf of Maine Area Closure (WGoMAC) established in 1998 (Fig. 1A). This closure was a management response to the rapid decline of the Gulf of Maine cod (Gadus morhua) stock. This case study provides another example of how fishers' ecological knowledge (FEK) can be incorporated into scientific analyses to improve fishery management outcomes.

In the United States, all fisheries in federal waters, beyond the three-nautical mile limit of state waters and within the 200nautical mile limit of national jurisdiction, are managed under the Magnuson-Stevens Fishery Conservation and Management Act (MSFCMA) of 1976 (16 U.S.C. 1801 et seq.). This legislation created eight regional councils with the purpose of developing and amending Fishery Management Plans (FMPs), and charged the Department of Commerce, through the National Marine Fisheries Service (NMFS), with the management of marine fisheries. In this organizational scheme, each of the councils is an advisory body to the NMFS. Councils' recommendations can be overridden by the NMFS but only under stringent conditions set out in the enabling legislation. The relevant council in this study was the New England Fishery Management Council (NEFMC).

Initial creation of area closures in this management region, for the purpose of reducing fishing mortality, started in 1994 when the NEFMC implemented two large area closures on Georges Bank (Fig. 2; Murawski et al. 2000). These closures shifted fishing effort into the Gulf of Maine raising concerns about the effect of increasing effort there. Initial consideration of the Western Gulf of Maine region as a potential area closure occurred during the NEFMC meetings in 1996. When first proposed, the WGoMAC did not have its current shape, size, or duration. Varying options were considered over the next two years. These ranged from year-round to seasonal (rolling) closures implemented in areas of various sizes and shapes (Fig. 1B). In the end, on December 15, 1997, the NEFMC created the WGoMAC, a year-round closure of approximately 3100 $\mathrm{km}^{2}$ located off the coasts of northern Massachusetts, New Hampshire, and southern Maine (Groundfish Committee Meeting: December 15, 1997; Framework Adjustment 25 to the Northeast Multispecies Fishery Management Plan 1998; 
Fig. 1. Western Gulf of Maine Area Closure (WGoMAC): (A) Size and location of the WGoMAC in relation to the Atlantic cod (Gadus morhua) essential fish habitat (EFH) for juvenile and adult stages. Data on EFH obtained from the NOAA Fisheries, Office of Habitat Conservation. (B) Area Closure (AC) proposals during the development process of the WGoMAC. Jeffrey's Ledge AC (purple) and Six-month AC (green) were substituted by WGoMAC (red) as the final measure. Numbered squares (30 ft) are statistical units used for reporting landings.

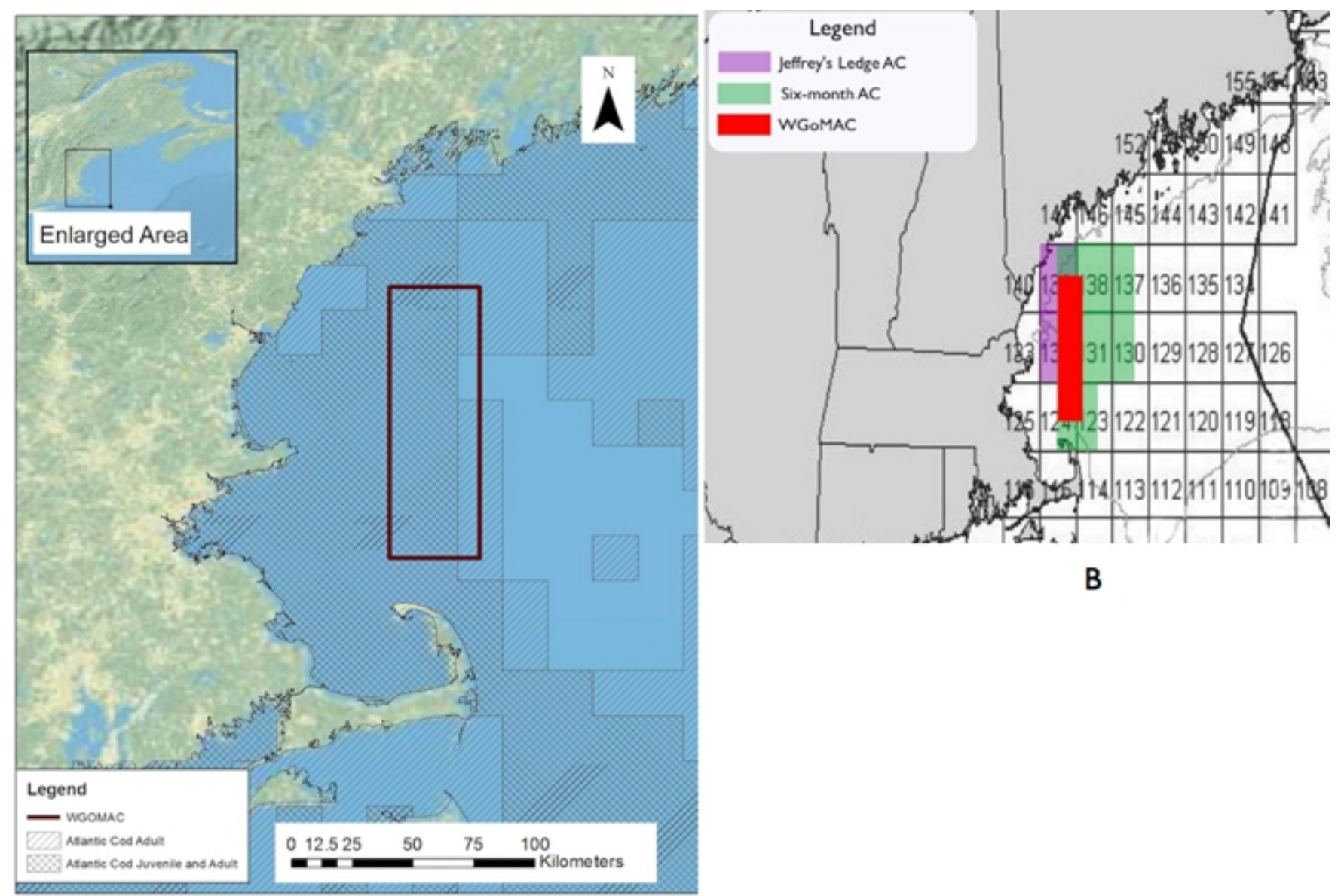

A

Figure 1A). The regulation created a year-round closure and prohibited any commercial vessel with gear capable of catching multispecies groundfish from fishing the closure (Framework Adjustment 25 to the Northeast Multispecies Fishery Management Plan 1998). It came into effect on May 1,1998 .

During the creation process, area closure options were evaluated based on landings data, which are reported at the scale of $30 \mathrm{ft}$ squares (approximately $2300 \mathrm{~km}^{2}$ ). The final location of the WGoMAC spreads across 6 different $30 \mathrm{ft}$ squares, without including a single square in its entirety; this suggests that managers used some additional information other than landings data to strategically position the closure (Fig. 1B). We hypothesized that FEK played a key role in this management decision. In addition, we also examined whether different stakeholder groups recognize FEK as a potential factor in policy creation and formulation.

\section{Fishers' ecological knowledge}

Fishers acquire ecological knowledge through observation, experience, and interaction with the local environment (Berkes and Folke 2002). As such, FEK is considered local ecological knowledge. However, as Berkes et al. (1998) point out, FEK is somewhat different from some other forms of ecological knowledge, such as indigenous and traditional, because it does not incorporate ethical values and beliefs into an existing knowledge system that, taken together, constitute a moral code toward the environment. 
Fig. 2. Area and habitat closures designated by the New England Fishery Management Council (NEFMC) as of 2007. The first two area closures (marked in red) were created on Georges Bank in 1994. Western Gulf of Maine Area Closure (WGoMAC; marked in blue) was created in 1998 (Framework Adjustment 25 to the Northeast Multispecies Fishery Management Plan). 2004 amendments (Amendment 13 to the to the Northeast Multispecies Fishery Management Plan) created habitat closures (marked with diamond pattern). In the case of WGoMAC, new regulations divided original area closure into habitat closure and rebuilding closure. (Map source: National Oceanic and Atmospheric Administration [NOAA] - National Marine Fisheries Service [NMFS], Northeast Regional Office [NERO]).

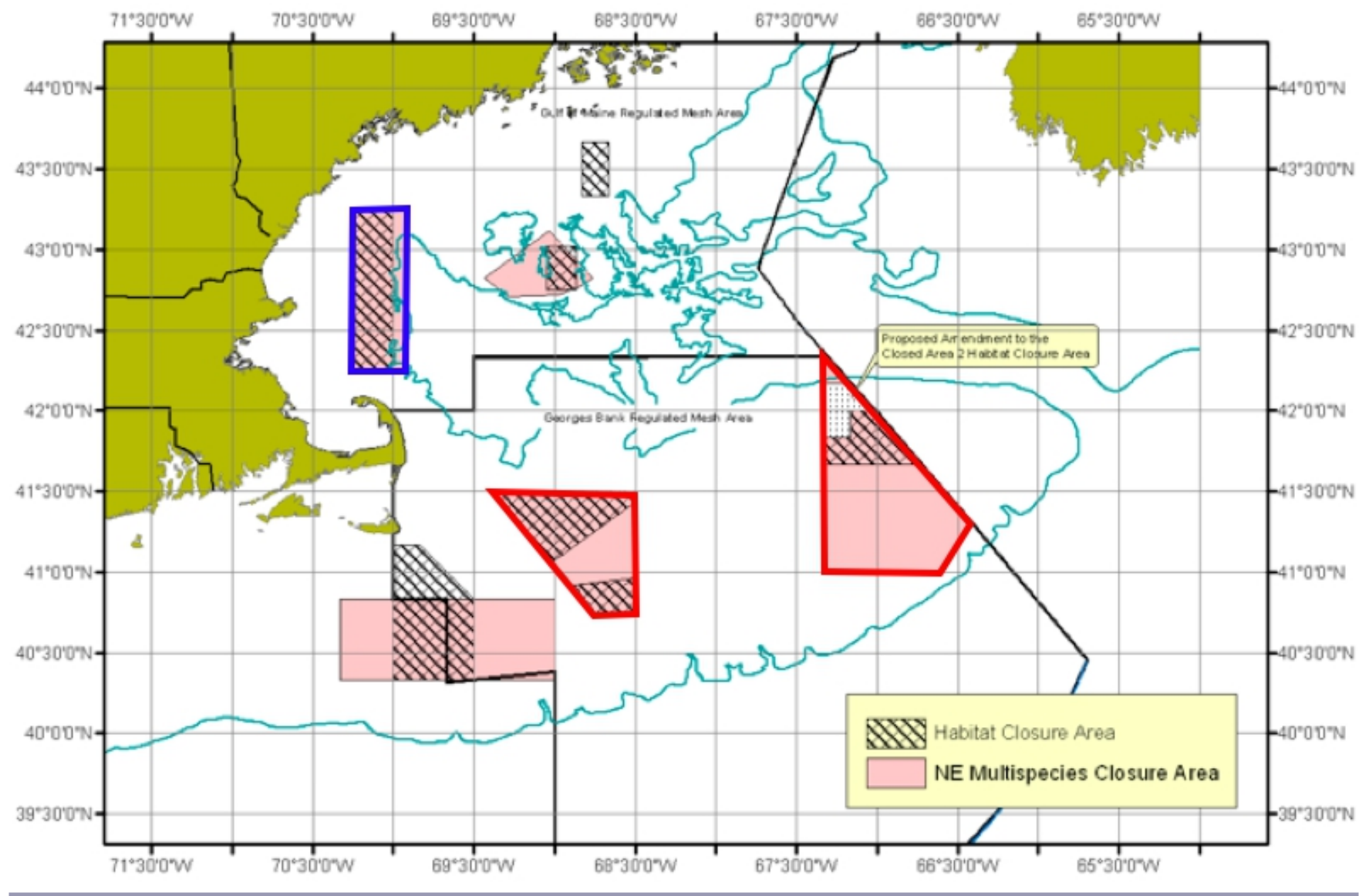

FEK is based on long-term continuous observations of the behavior of fish and their interaction with specific oceanographic conditions, e.g., currents, water temperature, depth, or bottom type, within a particular area (Thorlindsson 1994, Fischer 2000, Gosse et al. 2001, Berkes and Folke 2002, Murray et al. 2006). This kind of knowledge is characterized as highly informal (Thorlindsson 1994) and as very detailed and accurate (McKenna et al. 2008, Rochet et al. 2008). It is generated through active participation in the fishing process (Pálsson 1994) for which most information is not available in written form (Goose et al. 2001, Johannes and Neis 2007). Sharing of knowledge and information among fishers is uncommon (Ames et al. 2000, Ames 2003, cf. Gatewood 1984, Palmer 1991) but if it occurs, it is in a form of storytelling (Johannes and Neis 2007). One of the reasons for such dynamics, at least in nontraditional societies, is lack of incentives that encourage information sharing among fishers (Wilson 1990, 2006). However, the problem is that the secrecy of FEK can lead to permanent information loss because there is no codified form of FEK, unless it is transmitted through some form of communication from one generation to the next (Ames et al. 2000, Ames 2007). If not transmitted or codified, such knowledge would otherwise have been lost from fishers' culture, contributing to a "shifting baseline" syndrome (see Pauly 1995). Thus the public value of FEK is limited by its restricted spatial coverage, informality, oral communication, and secrecy.

Even though the literature suggests that FEK is relevant and valuable to fisheries science and management (e.g., Finlayson and McCay 1998, Gosse et al. 2001, Ames 2004, García- 
Quijano 2007), the administrative procedures of U.S. fishery management make it difficult to include expertise from outside the formal scientific realm (NRC 2004). Embedded within the management framework guided by the MSFCMA, fishery population dynamics is a highly quantitative scientific procedure used to identify and calculate biological reference points for individual commercial stocks and to provide quantitative advice on how that stock can be sustainably exploited (see 50 CFR $\S 600.310$, National Standard 1 Optimum Yield). Fishery population dynamics is based on the general concept that recruitment is a function of the size of the spawning stock where every individual stock can be treated as an autonomous unit (Wilson et al. 1994, Acheson and Wilson 1996, Beverton 1998, Wilson 2007). This view of single species management, which in itself is highly uncertain because of the complex nature of marine ecosystems, leads to even higher uncertainty associated with estimation of fish abundance. As Gunderson et al. (2002) point out, controlling just a single variable within a complex system can result in unpredictable changes that can cause the erosion of ecosystem resilience over time. Despite this high level of uncertainty, single species-based stock assessment remains the basis of fishery management decisions (Hilborn 2003, Clay and Olson 2008).

The spatial and temporal scales at which fishers and fisheries scientists observe and study marine ecosystems often differ significantly. Wilson (2006) explains that because marine ecosystems operate at multiple scales, the scientific knowledge used in fisheries management is insufficient because it addresses each species as if it was independent of the rest of the ecosystem and, further, considers only one broad scale and therefore misses fine-scale dynamics. Finlayson and McCay (1998) illustrate how Canadian government scientists were not able to predict the collapse of the inshore cod stocks in Newfoundland because the stock was managed as a single stock at a very large spatial scale. Similarly, Ames (2004) suggests that the collapse of the Gulf of Maine cod resource was a consequence of a scaling problem whereby stock assessments were insensitive to local stock dynamics.

Focusing only at the local level can also be misleading. As Gosse et al. (2001:25) point out, fishers' reasoning based on small-scale observations "may lead to an incomplete understanding of how nature [an ecosystem] works." For example, the perception of locally abundant or scarce pelagic fish is a function of changes in regional and local dynamics and may not be representative of the entire stock (see Mahon and McConney 2004). Similarly, Berkes (2006:10) points out that, "community-based resource management is vulnerable to external drivers and is often insufficient by itself to deal, for example, with problems of migratory marine resources." In addition, Wilson (2003:499) points out in his bluefish case study that the scale issue represented a large problem for the National Marine Fisheries Service (NMFS) when it wanted to incorporate fishers' observations to improve stock assessment because this hurdle "includes both the logistical issue of processing detailed information from a huge area, and the conceptual problem of translating local observation into meaningful information at a larger scale." This difficulty of translation can be essentially seen as a problem of institutional design, in which the relevant institutions are not equipped to deal with heterogeneity of information and variation in regulations (see Acheson 2006).

Therefore, understanding and linking knowledge acquired at multiple scales is required for successful management. As Cash et al. (2006:4) remark: "Ignoring cross-scale dynamics within spatial and temporal dimensions is common and leads to a range of management problems." Theoretical and empirical studies in various branches of ecology confirm that there is no single correct scale at which a system should be described (Levin 1992) and for that matter managed. As Levin (1992:1947) explains, there is a need to "recognize that change is taking place on many scales at the same time, and that it is the interaction among phenomena on different scales that must occupy our attention."

The decision to implement the WGoMAC illustrates the integration of information generated at multiple scales in fisheries management. In spite of the barriers to using FEK in policy making, managers relied upon FEK to determine fine scale boundaries of the closed area. We document attitudes about the value of FEK and further show that its use in combination with normal, broad scale management data led to a management decision that was ecologically more relevant than would have been possible if only one scale of data had been used.

\section{METHODS}

This case study emerged from communications with former fishery managers, Maine groundfishers, and academic scientists. It was conducted from December 2006 to January 2009 and focused on a single event, the creation of the WGoMAC over the period from May 1996 to March 1998. This period coincides with the initial development of the closure until its final implementation. To fully encompass all the relevant aspects of the closure implementation and to better understand the role of FEK, we used the embedded sequential design approach (Creswell and Plano Clark 2007). This is a mixed methods design in which the quantitative component of the study, a structured survey, was embedded within a qualitative design. The qualitative component of the method design consisted of a review of official documents regarding the creation and implementation of the WGoMAC and followup semistructured phone interviews with key informants. This design allowed us to systematically capture relevant data across a diverse set of groups and data sets that contained the information regarding the role of FEK in the creation and implementation of the WGoMAC. 
We started with the review of more than 150 government documents, including memoranda, letters and emails, studies and reports, as well as final rules and regulations that directly or indirectly related to the WGoMAC. The purpose of this review was to document the process through which the closure was established and to better understand the role of different stakeholders in this process. This allowed us to design a survey that would seek to further understand the contributions of FEK to the creation of the closure.

A structured survey was then sent to (1) Maine groundfishers, (2) NEFMC members, (3) Groundfish Advisory Panel (AP) members, and (4) Groundfish Plan Development Team (PDT) members (Table 1). These groups were chosen based on their active roles in the creation and implementation of the WGoMAC. Specific NEFMC, Groundfish AP, and Groundfish PDT members were selected based on their tenure with the council during the initiation of the development and subsequent regulation changes of the WGoMAC. Because of limited funds, only Maine groundfishers were selected to participate. Groundfishers were targeted specifically because they were principally affected by the implementation of WGoMAC and because they hold ecological knowledge about cod in the general area of the closure. The Groundfish AP provides information and advice to the NEFMC and consists of fishers, scientists, and members of the environmental community. The Groundfish PDT consists largely of fisheries scientists, regional fishery managers, and other experts in fisheries science and management. This group provides technical analyses and information for the NEFMC on fishery management alternatives.

The survey was divided into three sections: (1) general background information on respondents' education, work, and participation in fisheries management, (2) perceptions about the effectiveness of WGoMAC, and (3) degree and type of knowledge sharing between fishers, fishery managers, and scientists. The survey was self-administered and structured with a combination of closed and open-ended questions. A mail survey was distributed to Maine groundfishers while a web-based survey (www.qualtrics.com) was sent to the other three groups (see Rea and Parker 2005).

The last component of the embedded sequential design consisted of semistructured telephone interviews (Bernard 2006) with key informants. The informants were selected using a snowball sampling method (Rea and Parker 2005, Bernard 2006). Because the number of participants in our survey was small, we used these interviews to clarify and elaborate some of the information obtained from the survey. For example, questions were designed to further our understanding of the degree of knowledge sharing among scientists, managers, and fishers during the creation of the WGoMAC. Additionally, we sought a better understanding of the knowledge used to create the WGoMAC.
Table 1. Survey sample size and response rate.

\begin{tabular}{lccc}
\hline \hline $\begin{array}{l}\text { Survey Group/ } \\
\text { \# of Participants and Response } \\
\text { Rate }\end{array}$ & $\begin{array}{c}\text { Working } \\
\text { Popula- } \\
\text { tion }\end{array}$ & $\begin{array}{c}\text { \# of } \\
\text { Maine Groundfishers }\end{array}$ & $\begin{array}{c}\text { Response } \\
\text { Rate: } \% \\
\text { surveys } \\
\text { completed }\end{array}$ \\
\hline $\begin{array}{l}\text { New England Fishery } \\
\text { Management Council }\end{array}$ & 74 & 14 & 18.9 \\
$\begin{array}{l}\text { Groundfish Advisory Panel } \\
\text { Groundfish Plan Development } \\
\text { Team }\end{array}$ & 33 & 10 & 30.3 \\
\hline
\end{tabular}

'Information from 2005 obtained from the NMFS Northeast Region Federal Permit Database (www.nero.noaa.gov/permits). Participants were selected based on residence (state of Maine), home harbor (in the state of Maine), effective multispecies (groundfish) permit (Days at Sea A). ${ }^{*}$ Information obtained from the New England Fishery Management Council. Participants were selected based on their tenure with the NEFMC during the initiation of the development and subsequent regulation changes of the Western Gulf of Maine Area Closure.

${ }^{\S}$ Two slightly different surveys were distributed to the four groups. The first survey was developed for Maine groundfishers and it contained 53 questions. The second survey was developed for NEFMC, Advisory Panel, and Plan Development Team members and contained 46 questions. Questions regarding fishing practices and the history of fishing were omitted in managers' survey whereas questions regarding management practices and an individual's role(s) in the fisheries management process (as NEFMC members, advisors, and researchers) were omitted in fishers' survey (for detailed information see Nenadovic 2009a).

Numerical data from the questionnaires were compiled into Excel spreadsheets separately for each group. Data were analyzed using descriptive statistics. Qualitative data from government documents and interviews, including comments from the survey, were entered into Word documents. Data were analyzed using a combination of inductive and deductive methods (Fereday and Muir-Cochrane 2006). The initial coding template was based on our research question. Upon the initial qualitative data analysis, additional themes began to emerge and the initial coding template was sequentially modified through an iterative process until all the major themes were identified and captured. Each theme contained a number of related issues (Table 2). References to the role of FEK in the creation of the closure were sorted based on the initial source, i.e., government documents, surveys, interviews. This approach allowed us to merge qualitative information from a number of different data collection methods and analyze them concurrently. Interpretation of qualitative data was supported by the results from quantitative data and vice versa.

\section{Limitations}

Results pertaining to the data obtained from a structured, selfadministered survey should be interpreted with care for the following reasons. First, our sample size was small because of initial constraints we placed on the potential survey participants. Because we wanted to limit participation only to those managers who were involved in the creation of the 
Table 2. Coding structure: major themes that were identified during the qualitative data analysis. These guidelines were used in Table 4. Not all themes were discussed in this paper.

\begin{tabular}{ll}
\hline \hline Theme (node) & Description \\
\hline Politics & $\begin{array}{l}\text { References and comments with regard to the role of politics in the creation of the Western Gulf of Maine Area Closure } \\
\text { (WGoMAC). The major issue was a perception that the closure was already predetermined when the process began. }\end{array}$ \\
Knowledge & $\begin{array}{l}\text { References and comments illustrating the different views of the knowledge related issues in the WGoMAC creation. Major } \\
\text { issues were perception that fishers' ecological knowledge (FEK) is anecdotal, that trust between the parties is lacking, that } \\
\text { knowledge sharing among stakeholders is selective and strategic, that scientific input was lacking from the closure } \\
\text { establishment, and that communication and information exchange between stakeholders needs to be improved. }\end{array}$ \\
& $\begin{array}{l}\text { Issues that were identified by different groups as problematic for achieving stated objectives of the closure include but are not } \\
\text { limited to recreational fishing, midwater trawling, overcapitalization, shift in fishing effort, and lack of new research activities. }\end{array}$ \\
Problems & $\begin{array}{l}\text { Potential solutions to aforementioned problems ranged from closing the WGoMAC to all fishing, limiting entry, expanding the } \\
\text { closure, reducing the closure, shifting the closure to some other area, to controlling the fishing methods within the closure. }\end{array}$
\end{tabular}

closure, we were not able to expand the sample size beyond the actual number of members who participated in the process. Even though we followed a standard procedure for administering mail-out and web-based surveys (Rea and Parker 2005), our response rate was low. Therefore, we used interviews with key informants to evaluate information obtained from the questionnaires to avoid any misinterpretation of data because of a small sample size.

Second, because the development and implementation of the WGoMAC occurred more than 10 years ago, participants' memory and interpretation of certain events might have changed, been forgotten, or influenced by more recent events. Biemer et al. (1991) point out that retrieval of information depends on the number of intervening events and the length of time that has passed between the occurrence of the event in question and the moment of recall, the salience of the event in question, and the interviewee's mood and other psychological characteristics at the time of the survey implementation. To reduce the impact of some of these factors on our survey results, we provided every interviewee with general information regarding the area closure, i.e., date of implementation, location, and size, to facilitate memory recall. Based on our initial conversations with fishers during the implementation and development of the study, we found that the creation of the closure was an event that was considered important and easily recalled. In addition, the survey was designed so each question was independent; none of the questions had to be answered to continue with the survey, an approach that is used to improve the accuracy of retrospective reports (Miller et al. 1997). Furthermore, the accuracy of the results from the survey was then further examined using the information obtained from the interviews with key informants.

Third, respondents in the Maine groundfishers group were largely small boat owners/captains, i.e., boats with length less than $15.2 \mathrm{~m}$, a sample composition that could have produced a biased view toward the effect of this regulation. However, this seems to be unlikely because the majority ( $76 \%$ on average from 1997-1998 and 2000-2005) of Maine boat owners/ captains with a permit to catch groundfish belonged to this group. Last, there is a possibility that some answers suffer from social desirability bias (DeMaio 1984).

The process of data evaluation relied not only on our knowledge about this event but also on our discussions with key informants who were able to verify and/or clarify a number of issues raised in our surveys.

\section{RESULTS}

\section{Structured surveys}

A total of 46 individuals were surveyed (Table 1). The highest response rate was from the Groundfish PDT (50.0\%), whereas the lowest rate was from Maine groundfishers (18.9\%; Table 1 ). The majority of groundfishers $(85.7 \%)$ did not believe that the public input mattered to the outcome of WGoMAC implementation (Table 3). They felt that the entire process was irrelevant and that the outcome was already predetermined, that is, the game of politics (Table 4). Alternatively, PDT, NEFMC, and AP members indicated that they believed that public input did matter $(100 \%, 60 \%$, and $50 \%$, respectively; Table 3).

\section{Perceptions about FEK and knowledge sharing}

A large number of all respondents $(94.9 \%)$ concluded that fishers possess ecological knowledge that could be used in the fishery management process (Table 5A). As one respondent stated, FEK consists of "detailed information on fishing and fish behavior including spatial distributions in relation to bottom type and oceanographic processes." 
Table 3. Participants' opinions about the importance of public input to the outcome of Western Gulf of Maine Area Closure establishment. Values in parentheses are percentages.

\begin{tabular}{lccccc}
\hline \hline & $\begin{array}{c}\text { NEFMC } \\
\mathrm{n}=5\end{array}$ & $\begin{array}{c}\text { AP } \\
\mathrm{n}=4\end{array}$ & $\begin{array}{c}\text { PDT } \\
\mathrm{n}=5\end{array}$ & $\begin{array}{c}\text { Fishers } \\
\mathrm{n}=14\end{array}$ & $\begin{array}{c}\text { Total } \\
\mathrm{n}=28\end{array}$ \\
\hline Important & $3(60.0)$ & $2(50.0)$ & $5(100.0)$ & $2(14.3)$ & $12(42.9)$ \\
Not important & $2(40.0)$ & $2(50.0)$ & $0(0.0)$ & $12(85.7)$ & $16(57.1)$ \\
\hline NEFMC = New England Fishery Management Council; AP = Advisory
\end{tabular}

However, a majority within each group recognized obstacles to the use of FEK in fishery management (Table 5B). Fourteen respondents indicated their view that FEK is considered anecdotal (Table 4). Only four out of 14 respondents believed that FEK had only anecdotal value while the rest of the respondents viewed this characterization of FEK as being a major issue. One respondent characterized FEK as "fine scale ecological information," while another indicated that, "most fishers have local knowledge, or perhaps 'small-scale' knowledge" where most "don't see the 'big picture' because they are too 'narrow' in their knowledge and vision."

FEK accuracy was also brought into question. Eleven respondents indicated there was a lack of trust between scientists and fishers and that knowledge sharing was selective and strategic (Table 4). One NEFMC member indicated that fishers tend to share knowledge only if it is in their economic interest, while one PDT member stated that fishers "only share what they want regulators to know, and often give misinformation to try to avoid having effective regulations." Although one fisher recognized "there are always outlaws as in all types of business," fishers generally did not agree with the assessment of selective knowledge sharing. One fisher blamed managers, pointing out that because fishers tend to lack advanced degrees, they are considered "a bunch of greedy fishers who would take the last fish from the ocean." The same respondent continued: "That is dead wrong, most of us are here for the long term and want to maximize our investments for the long run."

Responding NEFMC members and Maine groundfishers pointed to a conflict between fishers' and scientists' knowledge during the establishment of the closure, yet believed that FEK was used in the process of closure establishment (Table 6A,B). In addition, the majority of PDT and AP members also agreed that FEK was used in the establishment of the closure (Table 6B). The majority of NEFMC members and groundfishers believed there was not enough communication and knowledge sharing between fishers, scientists, and managers during the process (Table $6 \mathrm{C})$.

Interestingly, a number of respondents felt that the WGoMAC was not established based on best scientific information available, as required under the MSFCMA, National Standard 2 (see 50 CFR 600.310). Five respondents held the view that science was not used at all in this process (Table 4). As one PDT member explained, "Scientists had absolutely nothing to do with creation of the WGoMAC." Some viewed the creation of the area closure as largely a game of politics, rather than having been based on either science or fishers' knowledge (Table 4). Many respondents suggested that fishers, through the process of public comment, helped design the boundaries for the WGoMAC. One PDT member indicated that the area closure was not established based only on the best scientific information available because "the initial closure proposed at the time was larger" and "based on a proposal from a fisher, the area was narrowed and is much smaller than the one originally proposed." This comment is supported by official NEFMC documents, which showed that the final boundaries of the WGoMAC are smaller than the ones considered during the process (Fig. 1A). One respondent indicated the value of fishers' "small-scale" knowledge to fishery management in the case of the WGoMAC establishment was that "scientists relied on data that was not as fine scale," and therefore they were not able to point to the exact area with the greatest cod aggregations, "...but when fishers proposed that area, scientists were able to look at the [landings] data again, and incorporate it in the framework action."

\section{Perceptions about WGoMAC effectiveness}

A majority of respondents viewed the WGoMAC as an effective measure in terms of reducing groundfish mortality, protecting habitat that groundfish require, and helping in the long-term recovery of groundfish stocks (Table 7). Groundfishers and PDT members viewed the closure as being the most effective in protecting habitat that groundfish require while the majority of NEFMC members believed the closure was the most beneficial for the long-term recovery of groundfish stock (Table 7).

\section{Semistructured interviews}

Follow-up semistructured interviews further clarified the use of FEK in the establishment of the WGoMAC. One fisher stated that they were the ones who asked the NEFMC for the specific area to be closed:

...they [the NEFMC] were going to close something and we wanted to get the correct area closed. The fleet knew that shoaler than 70 fathoms [128 m] there was a large biomass of juvenile cod fish. So we thought that if we participated in helping the regulators close the right area we would protect small cod from being taken out of the biomass...

A NEFMC member indicated that NMFS had landings data on the location and presence of cod in the Gulf of Maine but the resolution of that data was low (averaged across $30 \mathrm{ft}$ square statistical blocks, $\approx 2300 \mathrm{~km}^{2}$ ). PDT member stated that fishers, through a number of workshops organized by the NEFMC, identified important areas for cod in the Western 
Table 4. Major themes identified in participants' comments in the surveys related to the establishment of Western Gulf of Maine Area Closure (WGoMAC) and the use of fishers' ecological knowledge (FEK). Themes (capitalized, bold letters) were divided into a number of different subthemes (lower case letters) that appeared most frequently. For example, 12 out of 13 fishers identified politics as being an important factor in the process of WGoMAC creation. Out of those 12 fishers, seven had a specific comment that the closure boundaries were "already a done deal." Columns represent four surveyed groups.

\begin{tabular}{|c|c|c|c|c|c|c|c|c|c|c|}
\hline \multirow{2}{*}{$\begin{array}{l}\text { GROUPS/THEMES } \\
\text { (and subthemes) }\end{array}$} & \multicolumn{2}{|c|}{ NEFMC } & \multicolumn{2}{|c|}{ AP } & \multicolumn{2}{|c|}{ PDT } & \multicolumn{2}{|c|}{ Fishers } & \multicolumn{2}{|c|}{ Total } \\
\hline & $\mathrm{n}=9$ & in $\%$ & $\mathrm{n}=7$ & in $\%$ & $\mathrm{n}=14$ & in $\%$ & $\mathrm{n}=13$ & in $\%$ & $n=43$ & in $\%$ \\
\hline GAME OF POLITICS: & 7 & 77.8 & 3 & 42.9 & 8 & 57.1 & 12 & 92.3 & 30 & 69.8 \\
\hline Closure already a done deal & 1 & 11.1 & 0 & 0.0 & 0 & 0.0 & 7 & 53.8 & 8 & 18.6 \\
\hline OBSTACLES TO KNOWLEDGE & 9 & 100.0 & 7 & 100.0 & 12 & 85.7 & 13 & 100.0 & 41 & 95.3 \\
\hline \multicolumn{11}{|l|}{ SHARING: } \\
\hline FEK considered anecdotal & 5 & 55.6 & 4 & 57.1 & 2 & 14.3 & 3 & 23.1 & 14 & 32.6 \\
\hline Lack of trust / sharing false information & 4 & 44.4 & 1 & 14.3 & 2 & 14.3 & 4 & 30.8 & 11 & 25.6 \\
\hline Knowledge sharing selective/strategic & 1 & 11.1 & 0 & 0.0 & 2 & 14.3 & 1 & 7.7 & 4 & 9.3 \\
\hline OTHER ISSUES: & 9 & 100 & 7 & 100 & 14 & 100 & 13 & 100 & 43 & 100 \\
\hline Science not used in WGoMAC establishment & 1 & 11.1 & 1 & 14.3 & 1 & 7.1 & 2 & 15.4 & 5 & 11.6 \\
\hline $\begin{array}{l}\text { Collaborative research as a way to improve } \\
\text { communication }\end{array}$ & 1 & 11.1 & 3 & 42.9 & 2 & 14.3 & 2 & 15.4 & 8 & 18.6 \\
\hline
\end{tabular}

NEFMC = New England Fishery Management Council; AP = Advisory Panel; PDT = Plan Development Team

Gulf of Maine. In addition, during our review of the NEFMC documentation pertaining to the WGoMAC creation, one document from an unpublished written correspondence among council members dated 1997 emphasized the importance of this particular area for juvenile cod, based on their behavioral characteristics and migration patterns:

The cod, in deep water during the winter, start to school-up in Wilkinsons and Murray Basin, with larger vessels taking some big landings in February and March. Wildcat Knoll is very big in March. April and May, the cod come into the shoal water on Stellwagen, Tillies, Jeffery's Ledge and Platts to feed a little after the long winter. Then in April, May and June the ripe ones disperse to spawn in near-shore grounds from Mass and Ipswich Bays to Penobscot Bay, while the juveniles linger. The proposed area closure seeks to create a corridor for these prespawning, schooling fish.

According to a NEFMC member directly involved in this process, this information was obtained from a group of groundfishers that were actively fishing in the area. Groundfishers shared their knowledge of this particular area and agreed that the joint statement was consistent with their observations.

\section{DISCUSSION}

Although the management value of FEK is recognized, a key fishery management problem is how to incorporate this qualitative knowledge with quantitative scientific information. The results of this study show that the fishery management process can benefit considerably from the use of FEK. This study showed that this type of knowledge played an important role in the creation of the WGoMAC. Groundfishers provided information on the seasonal migration patterns of prespawning cod and indicated behavioral differences between juvenile and adult cod, which provided managers with the information needed to close an area with the highest probability of protecting the ecological integrity of the Gulf of Maine cod stock. Even though 12 out of 14 fishers indicated that the public input did not matter in the creation of the WGoMAC (Table 3 ) and that they viewed the entire process as being heavily politicized (Table 4), the majority of fishers still believed that FEK was used in the process of closure establishment (Table 6B). This apparent contradiction might suggest that fishers' input was channeled through a medium other than public comment. Key informants pointed out that the public comment period did play a role but that it was not the only mode of FEK transmission. In addition, FEK entered the NEFMC process of WGoMAC creation via workshops organized by the NEFMC as well as through the informal communication of NEFMC members, some of whom were fishers themselves, with their peers.

In the creation of the WGoMAC, managers were able to combine the information from both FEK and science. Scientific recommendations were based on analysis of quantitative landings data, which allowed for the spatial determination of the statistical blocks with the highest cod abundances in the Gulf of Maine (MSMC 1997). The standardized landings data did not capture some of the finerscale ecological information about cod seasonal migrations and the behavioral differences between juvenile and adult cod. Our study suggests this data analysis was further refined by FEK. Because FEK incorporates observations at a scale or over an area generally different from those used by fisheries scientists and managers, this refinement resulted in the creation of an area closure that is smaller than the options 
Table 5. Opinion about fishers' ecological knowledge (FEK) for each of the surveyed groups: (A) Do fishers possess FEK? (B) Are there obstacles to the use of FEK in fishery management? Values in parentheses are percentages.

\begin{tabular}{|c|c|c|c|c|c|}
\hline & $\begin{array}{c}\text { NEFMC } \\
\mathrm{n}=9\end{array}$ & $\begin{array}{c}\mathrm{AP} \\
\mathrm{n}=7\end{array}$ & $\begin{array}{c}\text { PDT } \\
\mathrm{n}=10\end{array}$ & $\begin{array}{l}\text { Fishers } \\
\mathrm{n}=13\end{array}$ & $\begin{array}{c}\text { Total } \\
\mathrm{n}=39\end{array}$ \\
\hline \multicolumn{6}{|c|}{ (A) Fishers possess FEK? } \\
\hline Yes & $8(88.9)$ & $7(100.0)$ & $9(90.0)$ & $13(100.0)$ & 37 (94.9) \\
\hline No & $0(0.0)$ & $0(0.0)$ & $1(10.0)$ & $0(0.0)$ & $1(2.6)$ \\
\hline Don't know & $1(11.1)$ & $0(0.0)$ & $0(0.0)$ & $0(0.0)$ & $1(2.6)$ \\
\hline \multicolumn{6}{|c|}{ (B) Obstacles to the use of FEK? } \\
\hline Yes & $7(77.8)$ & $6(85.7)$ & $8(80.0)$ & $12(92.3)$ & 33 (84.6) \\
\hline No & $1(11.1)$ & $0(0.0)$ & $0(0.0)$ & $0(0.0)$ & $1(2.6)$ \\
\hline Don't know & $1(11.1)$ & $1(14.3)$ & $2(20.0)$ & $1(7.7)$ & $5(12.8)$ \\
\hline
\end{tabular}

considered early in the creation process (Fig. 1A). The current WGoMAC spans part of six statistical blocks, four of which had the highest cod landings for 1993 and 1996 (MSMC 1997), which was the basis for area closure evaluation. No combination of entire statistical blocks could have encompassed the important ecological area without simultaneously including large, less relevant areas.

As one of the NEFMC members indicated, the fine-tuning of scientific information with FEK allowed managers to create a closure that protected some of the most important grounds for Gulf of Maine cod stock. Protecting shallow water and extending the closure to the east was crucial because these were the places groundfishers indicated as being full of juvenile cod in the former case, and prespawning schooling cod in the latter. The overall effectiveness of this management decision, based on the respondents' answers, is considered positive (Table 7). Although fishers' perceptions of both short and long-term changes in fish abundance have been considered accurate (McKenna et al. 2008, Rochet et al. 2008), there is very little fishery-independent data that could be used to test the effectiveness of this closure for improving the status of the Gulf of Maine cod stock. Official estimates indicate that both total biomass and spawning stock biomass of the Gulf of Maine cod stock increased from 1998 to 2004 (Mayo and Terceiro 2005). However, this increase could not be attributed solely to the implementation of the closure but rather to a number of management decisions that preceded and followed this particular regulation. On the other hand, habitat monitoring studies that were conducted in this region suggest that closure implementation had a positive effect on the habitat by increasing the abundance of benthic structure forming organisms (Knight 2005, Nenadovic 2009b).

The WGoMAC process shows the benefits of supplementing broad scale scientific information with finer scale ecological knowledge provided by fishers. It is also probably very important that the finer scale information provided by fishers was consistent with the broad scale information provided by scientists. Cash et al. (2006) suggest that these kinds of interactions and linkages result in better problem assessment and politically and ecologically more sustainable solutions. Similarly, as Reed (2008:2425) points out, the combination of two knowledge systems "can contribute to a more comprehensive understanding of complex and dynamic natural systems and processes" and the incorporation of FEK and broader stakeholder participation in the management process results in more effective and long-lasting management decisions and outcomes. This comment is especially relevant to our study because the analysis conducted by the U.S. Government Accountability Office (2006) found that all of the four regional councils it reviewed, one of them being NEFMC, are unsuitable for securing effective stakeholder participation.

In addition to providing valuable ecological information at a scale different from the one provided by fisheries science, FEK can be useful also in situations where scientific information is lacking or a scientific consensus on a particular subject is not reached. As Collins and Evans (2002:235) indicate, "the speed of political decision-making is faster than the speed of scientific consensus formation." In these kinds of management situations for which time is limited, FEK can play an important role by providing information that might not otherwise be available in the same time frame. In situations where time is less constraining, FEK can be scientifically tested and incorporated into fishery management through the process of collaborative research (Hutchings 1996).

In this study, several interviewees recognized collaborative research as a tool that bridges FEK and science. As one fisher indicated, "knowledge and information sharing between fishers and scientists are strong among those who have worked collaboratively together." Johnson and van Densen (2007:834) indicated that direct benefits of cooperative research included "increased quantity and quality of data, inclusion of fishers' knowledge in science and management, improved relevance of research to fisheries management, and reduced costs of science." Recent studies of collaborative research have identified it as a medium for knowledge sharing 
Table 6. Opinion about the creation of the Western Gulf of Maine Area Closure (WGoMAC) for each of the surveyed groups: (A) Was there conflict between the two knowledge systems during the establishment of the closure? (B) Was fishers' ecological knowledge (FEK) used in the process of closure establishment? and (C) Were there sufficient levels of communication and knowledge sharing between fishers, scientists, and managers? Values in parentheses are percentages.

\begin{tabular}{|c|c|c|c|c|c|}
\hline & NEFMC & $\mathrm{AP}$ & PDT & Fishers & Total \\
\hline $\begin{array}{l}\text { (A) Was there conflict between FEK and } \\
\text { Science? }\end{array}$ & $\mathrm{n}=9$ & $\mathrm{n}=6$ & $\mathrm{n}=10$ & $\mathrm{n}=13$ & $\mathrm{n}=38$ \\
\hline Yes & $5(55.6)$ & $2(33.3)$ & $4(40.0)$ & $9(69.2)$ & $20(52.6)$ \\
\hline No & $2(22.2)$ & $2(33.3)$ & $1(10.0)$ & $1(7.7)$ & $6(15.8)$ \\
\hline Don't know & $2(22.2)$ & $2(33.3)$ & $5(50.0)$ & $3(23.1)$ & $12(31.6)$ \\
\hline (B) Was FEK used? & $\mathrm{n}=9$ & $\mathrm{n}=6$ & $\mathrm{n}=10$ & $\mathrm{n}=12$ & $\mathrm{n}=37$ \\
\hline Yes & $6(66.7)$ & $4(66.7)$ & $6(60.0)$ & $7(58.4)$ & $23(62.2)$ \\
\hline No & $2(22.2)$ & $2(33.3)$ & $0(0.0)$ & $4(33.3)$ & $8(21.6)$ \\
\hline Don't know & $1(11.1)$ & $0(0.0)$ & $4(40.0)$ & $1(8.33)$ & $6(16.2)$ \\
\hline $\begin{array}{l}\text { (C) Was there knowledge sharing and } \\
\text { communication? }\end{array}$ & $\mathrm{n}=9$ & $\mathrm{n}=6$ & $\mathrm{n}=9$ & $\mathrm{n}=12$ & $\mathrm{n}=36$ \\
\hline Yes & $3(33.3)$ & $0(0.0)$ & $3(33.3)$ & $1(8.3)$ & $7(19.4)$ \\
\hline No & $4(44.5)$ & $3(50.0)$ & $2(22.2)$ & $7(58.4)$ & $16(44.5)$ \\
\hline Don't know & $2(22.2)$ & $3(50.0)$ & $4(44.5)$ & $4(33.3)$ & $13(36.1)$ \\
\hline
\end{tabular}

NEFMC = New England Fishery Management Council; AP = Advisory Panel; PDT = Plan Development Team

and a channel for FEK's incorporation into fishery management (St. Martin et al. 2007, Johnson 2010, 2011). Seen from this perspective, active and effective collaboration between fishers and scientists in a large part depends on level of social capital, i.e., trust, respect, and network connections, present between the two groups (Williams and Bax 2003). However, results from our study suggest that a lack of trust and a perception of selective knowledge sharing among involved parties are some of the major obstacles to the use of FEK in the fisheries management (Tables 4, 5B). As Soto (2006) points out, dominant Western conceptualizations of science prevent effective generation of social capital by marginalizing the role and/or value of FEK. In many instances this leaves fishers feeling disassociated from the management process (Butler 2005, Soto 2006).

More research is needed to fully understand why fishers shared their knowledge in this study and why they perceived politics as such a big obstacle to active participation. With regard to knowledge sharing, and according to a NEFMC member, not only did fishers share their knowledge with scientists and managers, but the FEK that was used in this case was also a product of collaboration among fishers who communicated and shared their knowledge to create a product on which they all agreed. It seems that NEFMC played an important role in this process. As one PDT member indicated, part of this process was facilitated by NEFMC through a series of workshops that were specifically organized to obtain fishers' knowledge and perspectives. This process of verbal peerreview among fishers was essential for its validity and use in fishery management. This was unexpected given that knowledge sharing among fishers and between fishers and scientists/managers is uncommon because secrecy of information is often essential for fishers' economic success (Wilson 1990, Thorlindsson 1994, Ames et al. 2000). With regard to politics, it is evident that a high number of respondents recognized politics as a relevant factor that influenced this process (Table 4). It is important to acknowledge that the interaction between FEK and science occurred within the decision making forum that was also impacted and shaped by political forces and power relations among different actors (Eagle et al. 2003, Okey 2003, Brzezinski et al. 2010). Therefore, the effects of politics on this process should be further investigated.

The WGoMAC case also confirms that the qualitative nature of FEK should not be viewed as preventing its use in management. The major problem stems from misapprehending the concept of anecdotal information and identifying it with FEK. One respondent explained how "anecdotal ecological information is difficult to incorporate into traditional assessment biology and management." A NEFMC member indicated that FEK is considered anecdotal and is difficult to incorporate into the management process. Yet, he also argued that, "it is extremely useful in providing guidance to managers." Indeed, as Wilson (2005:3) explains, characterizing knowledge as anecdotal does not diminish its validity; it simply describes a particular observation that "cannot be used to characterize phenomena at higher scale levels." Similarly, the qualitative nature of FEK makes its use in quantitative analyses, such as stock assessment, difficult (Pálsson 1998, St. Martin et al. 2007). However, there are ways FEK can be incorporated in fisheries management to expand "the basis for interpreting quantitative surveys used in fisheries 
Table 7. Opinion about the effectiveness of the Western Gulf of Maine Area Closure (WGoMAC) for each of the surveyed groups: (A) Does the closure reduce fishing mortality? (B) Does the closure protect habitat that groundfish require? and (C) Does the closure help in the long-term recovery of groundfish stocks? Values in parentheses are percentages.

\begin{tabular}{|c|c|c|c|c|c|}
\hline & NEFMC & $\mathrm{AP}$ & PDT & Fishers & Total \\
\hline (A) Closure reduces fishing mortality & $\mathrm{n}=9$ & $\mathrm{n}=6$ & $\mathrm{n}=12$ & $\mathrm{n}=13$ & $\mathrm{n}=40$ \\
\hline Yes & $6(66.7)$ & $4(66.7)$ & $6(50.0)$ & $6(46.2)$ & $22(55.0)$ \\
\hline No & $2(22.2)$ & $1(16.7)$ & $2(16.7)$ & $4(30.8)$ & $9(22.5)$ \\
\hline Don't know & $1(11.1)$ & $1(16.7)$ & $4(33.3)$ & $3(23.1)$ & $9(22.5)$ \\
\hline (B) Closure protects habitat & $\mathrm{n}=9$ & $\mathrm{n}=5$ & $\mathrm{n}=12$ & $\mathrm{n}=14$ & $\mathrm{n}=40$ \\
\hline Yes & $6(66.7)$ & $2(40.0)$ & $9(75.0)$ & $11(78.6)$ & $28(70.0)$ \\
\hline No & $1(11.1)$ & $1(20.0)$ & $1(8.3)$ & $2(14.3)$ & $5(12.5)$ \\
\hline Don't know & $2(22.2)$ & $2(40.0)$ & $2(16.7)$ & $1(7.1)$ & $7(17.5)$ \\
\hline (C) Closure helps in the long-term recovery & $\mathrm{n}=9$ & $\mathrm{n}=6$ & $\mathrm{n}=12$ & $\mathrm{n}=14$ & $\mathrm{n}=41$ \\
\hline Yes & $7(77.8)$ & $4(66.6)$ & $7(58.3)$ & $7(50.0)$ & $25(61.0)$ \\
\hline No & $0(0.0)$ & $1(16.7)$ & $2(16.7)$ & $3(21.4)$ & $6(14.6)$ \\
\hline Don't know & $2(22.2)$ & $1(16.7)$ & $3(25.0)$ & $4(28.6)$ & $10(24.4)$ \\
\hline
\end{tabular}

NEFMC = New England Fishery Management Council; AP = Advisory Panel; PDT = Plan Development Team

assessments" (Neis et al. 1999:1949). Australia, for example, is compiling and evaluating FEK for the purpose of better understanding long-term changes in fish stocks (AFMF 2006). For ecological issues that can be qualitatively described, e.g., vulnerable habitats, spawning aggregations, juvenile aggregations, or fish migration patterns, FEK can be directly incorporated into fishery management, such as in the placement of marine protected areas (MPAs; Aswani and Lauer 2006). This is especially relevant because a number of scientists view MPAs as a basic precautionary strategy for achieving both fishery management and conservation goals (Cooke and Earle 1993, Auster 2001).

\section{CONCLUSION}

Even though FEK was used in the decision making process of the WGoMAC implementation, our findings highlight a number of problems in respect to this process. The respondents believed that there was a conflict between FEK and scientific knowledge partially due to a lack of trust between the involved parties, as well as obstacles to the use of FEK in fisheries management due to the perception that FEK was considered anecdotal. Furthermore, fishers viewed the public input process as ineffective for communicating their knowledge and views.

With this in mind, how can we achieve systematic incorporation of FEK into the current structure of fishery management in New England? We suggest that the answer to this question lies in securing greater and active stakeholder participation. The NEFMC could achieve this goal by creating a more transparent decision making process with clear goals and objectives that is also open to all stakeholder groups from the beginning, allows for effective collection, exchange, and evaluation of ideas and knowledge, and is based on learning, trust, equity, and empowerment (U.S. Government
Accountability Office 2006, Reed 2008). In addition, it is essential that fishers, scientists, and managers perceive clear and measurable benefits of their active participation and knowledge sharing. However, it is important to keep in mind that addressing the issue of using FEK is dependent on the local context within which decisions are being made.

Furthermore, it is clear from our study that both science and FEK hold useful and valuable information. It is important to consider the issue of scale and recognize that the use of knowledge should be based on the management problem at hand. From this perspective, we believe that to effectively manage multiscale, complex systems and reduce some of their inherent uncertainty, we need to combine knowledge from multiple scales and different actors in the system. However, as we have previously mentioned, this is not an easy task because it requires active participation and an ongoing commitment of all the parties in the process. As seen in the case of the WGoMAC creation, the scale at which FEK operates complements knowledge gained by fishery science conducted at broader scales. Being able to combine both within a nested social-ecological system can allow us to see different aspects of the same system and to adaptively manage it across different scales.

Responses to this article can be read online at: http://www.ecologyandsociety.org/voll7/iss1/art20/ responses/

\section{Acknowledgments:}

This research was funded by the Kendall Foundation. We thank all the individuals who participated in this study. We also thank several members of the New England Fishery Management 
Council (NEFMC) and several Maine groundfishers for their assistance in collecting the information about the Western Gulf of Maine Area Closure and for providing us with its historical background and context. We are also indebted to NEFMC staff that helped us locate and retrieve documents related to this management action. We also thank Ana Zivanovic-Nenadovic, Samuel Hanes, and Luke Fairbanks for reviewing the manuscript and Danielle Brzezinski and Matthew Bowers for GIS assistance. Furthermore, we are grateful to the three anonymous reviewers whose valuable comments and suggestions greatly improved the quality of the manuscript. $M N$ would especially like to thank his MS thesis committee for providing him with guidance throughout this project.

\section{LITERATURE CITED}

Acheson, J. M. 2006. Institutional failure in resource management. Annual Review of Anthropology 35:117-134. http://dx.doi.org/10.1146/annurev.anthro.35.081705.123238

Acheson, J. M., and J. A. Wilson. 1996. Order out of chaos: the case for parametric fisheries management. American Anthropologist 98:579-594. http://dx.doi.org/10.1525/aa.1996 $\underline{98.3 .02 \mathrm{a} 00110}$

Agardy, T. S. 1997. Marine protected areas and ocean conservation. R. G. Landes Company \& Academic Press, Washington, D.C., USA.

Amendment 13 to the to the Northeast Multispecies Fishery Management Plan. 2004. 50 CFR § 648. U.S. Federal Register 69 (81):22906-22987.

Ames, E. P. 2004. Atlantic Cod stock structure in the Gulf of Maine. Fisheries 29:10-28. http://dx.doi.org/10.1577/1548-8446 (2004)29[10:ACSSIT]2.0.CO;2

Ames, T. 2003. Putting fishermen's knowledge to work: the promise and pitfalls. Pages 184-188 in N. Haggan, C. Brignall, and L. Wood, editors. Putting fishers' knowledge to work. Fisheries Center Research Reports, University of British Columbia, Vancouver, British Columbia, Canada.

Ames, T. 2007. Putting fishers' knowledge to work: reconstructing the Gulf of Maine cod spawning grounds on the basis of local ecological knowledge. Pages 351-361 in N. Haggan, B. Neis, and I. G. Baird, editors. Fishers' knowledge in fisheries science and management. United Nations Educational, Scientific and Cultural Organization, Paris, France.

Ames, T., S. Watson, and J. Wilson. 2000. Rethinking overfishing: insights from oral histories of retired groundfishermen. Pages 153-164 in B. Neis and L. Felt, editors. Finding our sea legs: linking fishery people and their knowledge with science and management. ISER Books, St. John's, Newfoundland, Canada.
Aswani, S., and M. Lauer. 2006. Incorporating fishermen's local knowledge and behavior into geographical information systems (GIS) for designing marine protected areas in Oceania. Human Organization 65:81-102.

Auster, P. J. 2001. Defining thresholds for precautionary habitat management actions in a fisheries context. North American Journal of Fisheries Management 21:1-9. http://dx. doi.org/10.1577/1548-8675(2001)021<0001:DTFPHM >2.0.CO;2

Australian Fisheries Management Forum (AFMF). 2006. National Research Strategic Plan For Australian Fisheries and Aquaculture 2007-2012. AFMF, Australian Government Department of Agriculture, Fisheries and Forestry, Canberra, Australia. [online] URL: http://www.dpiw.tas.gov.au/inter.nsf/ Attachments/SCAN-6YU2LW/\$FILE/AFMF\%20National\% 20Research\%20Plan\%20-\%20FINAL\%20for\%20distribution\% 20(17-08-06).pdf

Berkes, F. 2006. From community-based resource management to complex systems: the scale issue and marine commons. Ecology and Society 11(1): 45. [online] URL: http ://www.ecologyandsociety.org/vol11/iss1/art45/

Berkes, F., and C. Folke. 2002. Back to the future: ecosystem dynamics and local knowledge. Pages 121-146 in L. H. Gunderson and C. S. Holling, editors. Panarchy: understanding transformations in human and natural systems. Island Press, Washington, D.C., USA.

Berkes, F., M. Kisalalioglu, C. Folke, and M. Gadgil. 1998. Exploring the basic ecological unit: ecosystem-like concepts in traditional societies. Ecosystems 1:409-415. http://dx.doi.o $\mathrm{rg} / 10.1007 / \mathrm{s} 100219900034$

Bernard, H. R. 2006. Research methods in anthropology: qualitative and quantitative approaches. Fourth edition. Alta Mira Press, New York, New York, USA.

Beverton, R. 1998. Fish, fact and fantasy: a long view. Reviews in Fish Biology and Fisheries 8:229-249. http://dx.doi.org/10 .1023/A:1008888411100

Biemar, P. P., R. M. Groves, L. E. Lyberg, N. A. Mathiowetz, and S. Sudman. 1991. Measurement errors in surveys. John Wiley \& Sons, New York, New York, USA.

Brzezinski, D. T., J. Wilson, and Y. Chen. 2010. Voluntary participation in regional fisheries management council meetings. Ecology and Society 15(3): 2. [online] URL: http:// www.ecologyandsociety.org/vol15/iss3/art2/

Butler, C. F. 2005. More than fish: political knowledge in the commercial fisheries of British Columbia. Dissertation. University of British Columbia, Vancouver, British Columbia, Canada. 
Cash, D. W., W. N. Adger, F. Berkes, P. Garden, L. Lebel, P. Olsson, L. Pritchard, and O. Young. 2006. Scale and crossscale dynamics: governance and information in a multilevel world. Ecology and Society 11(2): 8. [online] URL: http://ww w.ecologyandsociety.org/vol11/iss2/art8/

Clay, P. M., and J. Olson. 2008. Defining "fishing communities": vulnerability and the Magnuson-Stevens Fishery Conservation and Management Act. Human Ecology Review 15:143-160.

Collins, H. M., and R. Evans. 2002. The third wave of science studies: studies of expertise and experience. Social Studies of Science 32:235-296. http://dx.doi.org/10.1177/030631270203 $\underline{2002003}$

Cooke, J., and M. Earle. 1993. Towards a precautionary approach to fisheries management. Review of European Community and International Environmental Law 2:252-259. http://dx.doi.org/10.1111/j.1467-9388.1993.tb00121.x

Creswell, J. W., and V. L. Plano Clark. 2007. Designing and conducting mixed methods research. Sage, Thousand Oaks, California, USA.

DeMaio, T. J. 1984. Social desirability and survey measurement: a review. Pages 257-282 in C. F. Turner and E. Martin, editors. Surveying subjective phenomena. Russell Sage Foundation, New York, New York, USA.

Eagle, J., S. Newkirk, and B. H. Thompson. 2003. Taking stock of the regional fisheries management councils. Island Press, Washington, D.C., USA.

Fereday, J., and E. Muir-Cochrane. 2006. Demonstrating rigor using thematic analysis: a hybrid approach of inductive and deductive coding and theme development. International Journal of Qualitative Methods 5:1-11.

Finlayson, A. C., and B. J. McCay. 1998. Crossing the threshold of ecosystem resilience: the commercial extinction of northern cod. Pages 311-338 in F. Berkes and C. Folke, editors. Linking social and ecological systems: management practices and social mechanisms for building resilience. Cambridge University Press, Cambridge, UK.

Fischer, J. 2000. Participatory research in ecological fieldwork: a Nicaraguan study. Pages 41-54 in B. Neis and L. Felt, editors. Finding our sea legs: linking fishery people and their knowledge with science and management. ISER Books, St. John's, Newfoundland, Canada.

Framework Adjustment 25 to the Northeast Multispecies Fishery Management Plan. 1998. 50 CFR § 648. U.S. Federal Register 63 (61):15326-15333.

García-Quijano, C. G. 2007. Fishers' knowledge of marine species assemblages: bridging between scientific and local ecological knowledge in southeastern Puerto Rico. American
Anthropologist 109:529-536. http://dx.doi.org/10.1525/aa.200 $\underline{7.109 .3 .529}$

Gatewood, J. B. 1984. Cooperation, competition, and synergy: information-sharing groups among Southeast Alaskan salmon seiners. American Ethnologist 11(2):350-370. http://dx.doi.or g/10.1525/ae.1984.11.2.02a00080

Gosse, K., J. Wroblewski, and B. Neis. 2001. Closing the loop: commercial fish harvesters' local ecological knowledge and science in a study of coastal cod in Newfoundland and Labrador, Canada. Pages 25-35 in N. Haggan, C. Brignall, and L. Wood, editors. Putting fishers'knowledge to work. Fisheries Center Research Reports, University of British Columbia, Vancouver, British Columbia, Canada.

Gunderson, L. H., L. J. Pritchard, C. S. Holling, C. Folke, and G. D. Peterson. 2002. A summary and synthesis of resilience in large-scale systems. Pages 249-266 in L. H. Gunderson and L. J. Pritchard, editors. Resilience and the behavior of largescale systems. Island Press, Washington, D.C., USA.

Hilborn, R. 2003. The state of the art in stock assessment: where we are and where we are going. Scientia Marina 67:15-20. http://dx.doi.org/10.3989/scimar.2003.67s115

Hutchings, J. A. 1996. Spatial and temporal variation in the density of northern cod and a review of hypotheses for the stock's collapse. Canadian Journal of Fisheries and Aquatic Sciences 53:943-962. http://dx.doi.org/10.1139/f96-097

Johannes, R. E., and B. Neis. 2007. The value of anecdote. Pages 41-58 in N. Haggan, B. Neis, and I. G. Baird, editors. Fishers' knowledge in fisheries science and management. United Nations Educational, Scientific and Cultural Organization, Paris, France.

Johnson, T. R. 2010. Cooperative research and knowledge flow in the marine commons: lessons from the Northeast United States. International Journal of the Commons 4:251-272. [online] URL: http://www.thecommonsjournal. org/index.php/ijc/article/viewArticle/ 110/110

Johnson, T. R. 2011. Fishermen, scientists, and boundary spanners: cooperative research in the US Illex squid fishery. Society and Natural Resources 24(3):242-255.

Johnson, T. R., and W. L. T. van Densen. 2007. Benefits and organization of cooperative research for fisheries management. ICES Journal of Marine Science 64:834-840. http://dx.doi.org/10.1093/icesjms/fsm014

Knight, E. P. 2005. The effects of trawling on benthic habitats: an analysis of recovery in the Western Gulf of Maine Closure. Thesis. University of Maine, Orono, Maine, USA.

Levin, S. A. 1992. The problem of pattern and scale in ecology. Ecology 73:1943-1967. http://dx.doi.org/10.2307/1941447 
Magnuson-Stevens Fishery Conservation and Management Act (MSFCMA). 1976. US Code Title 16: Conservation, Chapter 38: Fishery Conservation and Management.

Mahon, R., and P. A. McConney. 2004. Management of large pelagic fisheries in CARICOM countries. FAO Fisheries Technical Paper 464, Food and Agriculture Organization of the United Nations, Rome, Italy.

Mayo, R., and M. Terceiro, editors. 2005. Assessment of 19 Northeast groundfish stocks through 2004 - a report of the Stock Assessment Workshop (SAW) Northern and Southern demersal working groups. Document 05-13, Northeast Fisheries Science Center Reference Documents, Woods Hole, Massachusetts, USA.

McKenna, J., R. J. Quinn, D. J. Donnelly, and J. A. G. Cooper. 2008. Accurate mental maps as an aspect of local ecological knowledge (LEK): a case study from Lough Neagh, Northern Ireland. Ecology and Society 13(1): 13. [online] URL: http:// www.ecologyandsociety.org/vol13/iss1/art13/

Miller, C. C., L. B. Cardinal, and W. H. Glick. 1997. Retrospective reports in organizational research: a reexamination of recent evidence. Academy of Management Journal 40:189-204. http://dx.doi.org/10.2307/257026

Multispecies Monitoring Committee (MSMC). 1997. Report of the New England Fisheries Management Council's Multispecies Monitoring Committee. MSMC, Woods Hole, Massachusetts, USA.

Murawski, S. A., R. Brown, H. L. Lai, P. J. Rago, and L. Hendrickson. 2000. Large-scale closed areas as a fisherymanagement tool in temperate marine systems: the Georges Bank experience. Bulletin of Marine Science 66:775-798.

Murray, G., B. Neis, and J. P. Johnsen. 2006. Lessons learned from reconstructing interactions between local ecological knowledge, fisheries science, and fisheries management in the commercial fisheries of Newfoundland and Labrador, Canada. Human Ecology 34:549-571. http://dx.doi.org/10.1007/s1074 5-006-9010-8

National Research Council (NRC). 2002. Effects of trawling and dredging on seafloor habitat. National Academies Press, Washington, D.C., USA.

National Research Council (NRC). 2004. Improving the use of the "best scientific information available" standard in fisheries management. National Academies Press, Washington, D.C., USA.

Neis, B., D. C. Schneider, L. Felt, R. L. Haedrich, J. Fischer, and J. A. Hutchings. 1999. Fisheries assessment: what can be learned from interviewing resource users. Canadian Journal of Fisheries and Aquatic Sciences 56:1949-1963.

Nenadovic, M. 2009a. The process of implementing the Western Gulf of Maine Area Closure: the role and perception offisher's ecological knowledge. Thesis. University of Maine, Orono, Maine, USA.

Nenadovic, M. 2009b. The effects of bottom-tending mobile fishing gear and fiber-optic cable burial on soft-sediment benthic community structure. Thesis. University of Maine, Orono, Maine, USA.

Okey, T. A. 2003. Membership of the eight Regional Fishery Management Councils in the United States: are special interests over-represented? Marine Policy 27:193-206. http:/ /dx.doi.org/10.1016/S0308-597X(03)00002-2

Palmer, C. T. 1991. Kin-selection, reciprocal altruism, and information sharing among Maine lobstermen. Ethology and Sociobiology 12:221-235. http://dx.doi.org/10.1016/0162-3095 (91)90005-B

Pálsson, G. 1994. Enskilment at sea. Man 29:901-927. http:// dx.doi.org/10.2307/3033974

Pálsson, G. 1998. Learning by fishing: practical engagement and environmental concerns. Pages 48-66 in F. Berkes and C. Folke, editors. Linking social and ecological systems: management practices and social mechanisms for building resilience. Cambridge University Press, Cambridge, UK.

Pauly, D. 1995. Anecdotes and the shifting baseline syndrome of fisheries. Trends in Ecology and Evolution 10:430. http://d x.doi.org/10.1016/S0169-5347(00)89171-5

Rea, L. M., and R. A. Parker. 2005. Designing and conducting survey research: a comprehensive guide. Jossey-Bass, San Francisco, California, USA.

Reed, M. S. 2008. Stakeholder participation for environmental management: a literature review. Biological Conservation 141:2417-2431. http://dx.doi.org/10.1016/j.biocon.2008.07.014

Rochet, M.-J., M. Prigent, J. A. Bertrand, A. Carpentier, F. Coppin, J.-P. Delpech, G. Fontenelle, E. Foucher, K. Mahé, E. Rostiaux, and V. M. Trenkel. 2008. Ecosystem trends: evidence for agreement between fishers' perceptions and scientific information. ICES Journal of Marine Science 65:1057-1068. http://dx.doi.org/10.1093/icesjms/fsn062

Soto, C. G. 2006. Socio-cultural barriers to applying fishers' knowledge in fisheries management: an evaluation of literature cases. Dissertation. Simon Fraser University, Burnaby, British Columbia, Canada.

St. Martin, K., B. J. McCay, G. D. Murray, T. R. Johnson, and B. Oles. 2007. Communities, knowledge and fisheries of the future. International Journal of Global Environmental Issues 7:221-239. http://dx.doi.org/10.1504/IJGENVI.2007.013575

Thorlindsson, T. 1994. Skipper science: a note on the epistemology of practice and the nature of expertise. Sociology 
Quarterly 35:329-345. http://dx.doi.org/10.1111/j.1533-8525 1994.tb00413.x

U.S. Government Accountability Office (GAO). 2006. Fisheries management: core principles and a strategic approach would enhance stakeholder participation in developing quota-based programs. Report to Congressional Requesters, GAO-06-289. GAO, Washington, D.C., USA. [online] URL: www.gao.gov/new.items/d06289.pdf.

Williams, A., and N. Bax. 2003. Integrating fishers' knowledge with survey data to understand the structure, ecology, and use of a seascape off southeastern Australia. Pages 238-245 in N. Haggan, C. Brignall, and L. Wood, editors. Putting fishers' knowledge to work. Fisheries Center Research Reports, University of British Columbia, Vancouver, British Columbia, Canada.

Wilson, D. C. 2003. Examining the two cultures theory of fisheries knowledge: the case of bluefish management. Society \& Natural Resources 16:491-508. http://dx.doi.org/10.1080/0 $\underline{8941920309150}$

Wilson, D. C. 2005. Knowledge for commons management: a commons for the commons. Common Property Resource Digest 75:1-4.

Wilson, J. A. 1990. Fishing for knowledge. Land Economics 66:12-29. http://dx.doi.org/10.2307/3146679

Wilson, J. A. 2006. Matching social and ecological systems in complex ocean fisheries. Ecology and Society 11(1): 9. [online] URL: http://www.ecologyandsociety.org/vol11/iss1/ $\underline{\operatorname{art} 9 /}$

Wilson, J. A. 2007. Scale and the costs of fishery conservation. International Journal of the Commons 1:141-153.

Wilson, J. A., J. M. Acheson, M. Metcalfe, and P. Kleban. 1994. Chaos, complexity and community management of fisheries. Marine Policy 18:291-305. http://dx.doi.org/10.101 6/0308-597X(94)90044-2 